\title{
RADIOCARBON EVIDENCE FROM THE MIDDLE BRONZE AGE SETTLEMENT AT PORTELLA (AEOLIAN ISLANDS, ITALY): CHRONOLOGICAL AND ARCHAEOLOGICAL IMPLICATIONS
}

\author{
Gianmarco Alberti \\ Department of History and Preservation of the Cultural Heritage, University of Udine, Vicolo Florio 2, 33100 Udine, Italy. \\ Email: gianmarcoalberti@tin.it.

\begin{abstract}
This paper deals with radiocarbon determinations from the Middle Bronze Age site of Portella on the island of Salina (Aeolian Archipelago, Italy). The available ${ }^{14} \mathrm{C}$ evidence is taken into account, in a simple Bayesian model, in order to explore the issue of the absolute chronology of both the settlement and the stage of the local cultural sequence to which Portella belongs. A high date is proposed for the start of the Aeolian (and Sicilian) Middle Bronze Age: 1556-1422 cal BC (95.4\% confidence), with a a most likely (modal) date of about $1450 \mathrm{cal}$ BC. Further, the analysis suggests that the Portella phase is likely to have been a very short one, with a span of 0-65 yr (68.2\%) or 0-131 yr (95.4\%). The archaeological implications are explored. The relation of these results to the evidence of ceramic phasing is also considered. Since Aegean datable ceramic imports are documented in Aeolian/Sicilian Middle Bronze Age contexts, the connection between Portella's chronology and the absolute dating of one of the Aegean phases (namely, Late Helladic IIIA1) is also investigated.
\end{abstract}

\section{INTRODUCTION}

Middle Bronze Age (hereafter MBA; Table 1) Sicily, dated on a historical basis to 1400-1270 BC, features the incorporation of objects from different locations along the Mediterranean shores (Bernabò Brea and Cavalier 1968, 1980, 1991; Voza 1985; De Miro 1999; Castellana 2000). It is well known that pottery from Late Helladic (hereafter LH) Greece, Cyprus, Malta, and the Italian mainland, as well as jewelry, ivory, and gold items (all of possible east Mediterranean provenance), were deposited in MBA domestic and funerary contexts as result of long-distance maritime trade. These items often appear within the framework of social competition and display of social status (D'Agata 1997, 2000; Vagnetti 1999; van Wijngaarden 2002; Vianello 2005; Alberti 2006, 2007a).

Among these items, LH pottery has been used as a means for providing an absolute chronology beginning with the first pioneering archaeological research conducted at the end of the 19th century. Its use as a temporal marker became even more important in the following years as the chronological resolution of the changes in style and/or typology increased, providing an important means for dating finding contexts outside Greece (Taylour 1958, 1980; Vagnetti 1991).

Even though radiocarbon evidence began to be taken into account in Sicily during the 1960s (Alessio et al. 1980), its use as a means to build an independent chronology has been generally downplayed, perhaps due to the lack of research programs aimed at addressing specific chronological issues. The use of ${ }^{14} \mathrm{C}$ has been subordinated to chronologies based on historical means, namely absolute dates provided by imported Aegean pottery.

Importantly, as far as absolute dates are concerned, and allowing that imports can only provide a terminus post quem for the recipient contexts, converting the presence of Aegean ceramic styles into absolute dates turns out to be a complex matter. In fact, the chronology of the LH Aegean itself is undergoing a revision due to the ${ }^{14} \mathrm{C}$ evidence related to the Theran (Santorini) eruption contrasting with the chronological sequences devised by historical and archaeological synchronizations. Consequently, different scenarios regarding the absolute dates of the earlier stages of LH have been put forward by scholars, leading to the contrasting views of a high versus low chronology (Warren and Hankey 1989; Manning 1995, 1999, 2009; Warren 1998, 2009; Manning and Bronk Ramsey 2003; Wiener 2003a, 2009; Manning et al. 2006; Bietak 2007; Heinemeier et al. 2009). 
Table 1 Italian, Aeolian, and Sicilian archaeological phases from the Early Bronze Age (advanced) to Late Bronze Age. Inner phasing of Milazzese facies according to Alberti (2008a); inner phasing of Thapsos facies after Alberti (2004, 2007a). Late Helladic ceramic imports are shown (according to Alberti and Bettelli 2005; Jung 2006; Alberti 2008a), along with the approximate starting and ending dates (BC) of each ceramic phase according to the Aegean Low Chronology (derived from Warren and Hankey 1989; Warren 1998, 2009). The ${ }^{14} \mathrm{C}$ evidence from Portella suggests that the start of Milazzese facies is likely to occur around the mid-15th century BC. Note: slightly different dates are suggested by Wiener (2003b) for LH IIIA2: starting around 1390/75 BC; ending around 1330-1290 BC. Further, according to Jung (2006), the Italian Late Bronze Age is synchronous with the whole LH IIIB period, with no overlap between the early stage of that Aegean period and the Middle Bronze Age.

\begin{tabular}{|c|c|c|c|c|c|c|}
\hline \multicolumn{3}{|c|}{$\begin{array}{l}\text { Bronze Age phases defined on archaeological grounds } \\
\text { (facies) }\end{array}$} & \multirow{2}{*}{$\begin{array}{l}\text { Sicilian } \\
\text { Bronze Age } \\
\text { cultural } \\
\text { periods }\end{array}$} & \multirow[t]{2}{*}{$\begin{array}{l}\text { Aegean } \\
\text { imports }\end{array}$} & \multicolumn{2}{|c|}{$\begin{array}{c}\text { Approximate starting and } \\
\text { ending dates (BC) of the } \\
\text { Aegean phases } \\
\text { (Low Chronology) }\end{array}$} \\
\hline Mainland Italy & Aeolian Islands & Mainland Sicily & & & start & end \\
\hline \multirow{3}{*}{ ProtoApennine B } & \multirow{3}{*}{ Capo Graziano 2} & \multirow{3}{*}{$\begin{array}{l}\text { Castelluccio 2- } \\
\text { Rodì-Tindari- } \\
\text { Vallelunga }\end{array}$} & \multirow{3}{*}{$\begin{array}{l}\text { Early Bronze } \\
\text { Age } \\
\text { (advanced) }\end{array}$} & LH I & 1580 & 1530 \\
\hline & & & & LH II A & 1530 & 1470 \\
\hline & & & & LH II B & 1470 & $1400 / 1390$ \\
\hline \multirow{3}{*}{ Apennine } & Milazzese 1 & Thapsos 1 & \multirow{3}{*}{$\begin{array}{c}\text { Middle } \\
\text { Bronze Age }\end{array}$} & LH III A1 & $1400 / 1390$ & $1370 / 60$ \\
\hline & \multirow{2}{*}{ Milazzese 2} & Thapsos 2 & & LH III A2 & $1370 / 60$ & $1340 / 30$ \\
\hline & & Thapsos 3 & & & & \\
\hline \multirow{2}{*}{ SubApennine } & \multirow{2}{*}{ Ausonio I } & \multirow{2}{*}{ North Pantalica } & \multirow{2}{*}{$\begin{array}{c}\text { Late } \\
\text { Bronze Age }\end{array}$} & & & \\
\hline & & & & LH III C & $1185 / 80$ & 1065 \\
\hline
\end{tabular}

With a comprehensive examination of the ${ }^{14} \mathrm{C}$ evidence from MBA Sicily pending (being the subject of a current study by this author), this paper aims to analyze a specific aspect of the ${ }^{14} \mathrm{C}$ evidence from Sicily: the findings from the MBA settlement at Portella on the island of Salina (Aeolian Archipelago, Italy). The reason for taking into account the evidence from this site lies in the fact that, even though it represents just one facet of the issue, it bears a strong importance in the cultural and chronological aspects of its period.

In the following sections: a) first, a description will be provided of the cultural context as well as of the find context; b) the ${ }^{14} \mathrm{C}$ determinations will be analyzed, some comments will be made about the previous interpretation of this evidence, and an alternative scenario will be put forth; c) an evaluation will be proposed of the chronological and archaeological implications of these dates on the local culture's chronology and of the links with Aegean phasing.

\section{THE SETTLEMENT OF PORTELLA: ARCHAEOLOGICAL AND CULTURAL CONTEXT}

The site of Portella lies on Salina, one of the islands of the Aeolian Archipelago off the northeastern Sicilian shores (south Tyrrhenian region) (Figure 1). Excavations made in the 1940s by Bernabò Brea and Cavalier (1968) unearthed a MBA settlement, ascribed to the Milazzese culture, positioned on the steep slope of a rocky crest overlooking the shore (elevation 20-300 m asl) and made up of 10 huts (Figure 2). 

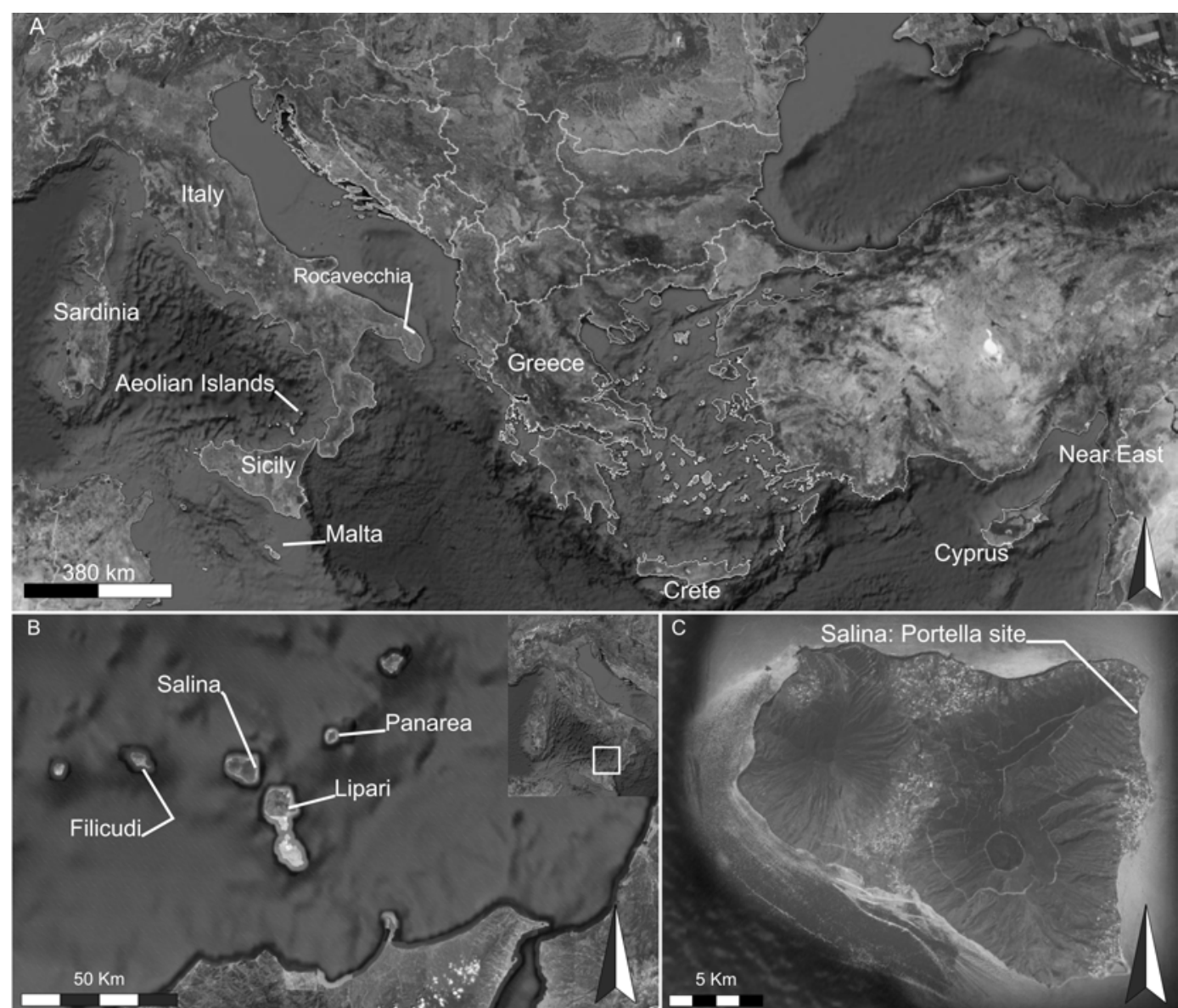

Figure 1 A) Mediterranean basin with indication of the main Bronze Age cultural areas and sites quoted in the text; B) Aeolian Archipelago: location of the main Middle Bronze Age settlements; C) Salina Island with location of Portella settlement. (A-C after Google Earth ${ }^{\circledR}$, modified)

The huts were subcircular, with floors and part of the walls cut into the slope. The roofs were made with wooden and other perishable materials. The settlement was inhabited only during the MBA and this, along with the geological nature of the sediments that filled the huts after their abandonment, assured the good preservation of the belongings the inhabitants left behind. These comprised ceramic inventories, made up of the typical gray handmade vessels with engraved decoration, stone and clay tools (mortars, grindstones, spindle whorls), a few items of jewelry, and pottery from the coeval Italian Apennine culture. One Mycenaean fragmentary vessel was found in hut F. Additional documentation has been provided by the recent excavations lead by M C Martinelli on this site in 2000, 2006, and 2008. While the publication of the 2006 and 2008 campaigns is pending, the 2000 campaign (Martinelli 2005) discovered a new group of 7 huts (huts L-R), along with some open areas (Figure 2C). Extra evidence for imports from the Italian mainland was added, as well as for imports from the Aegean area: sherds of a pithos with a clay composition suggesting a Cypriot origin were found (see remarks in Alberti 2007b).

The Portella settlement and its material culture share similarities with other Aeolian MBA villages of the Milazzese culture, like the ones on Panarea (site of Punta Milazzese), Filicudi (Montagnola di 


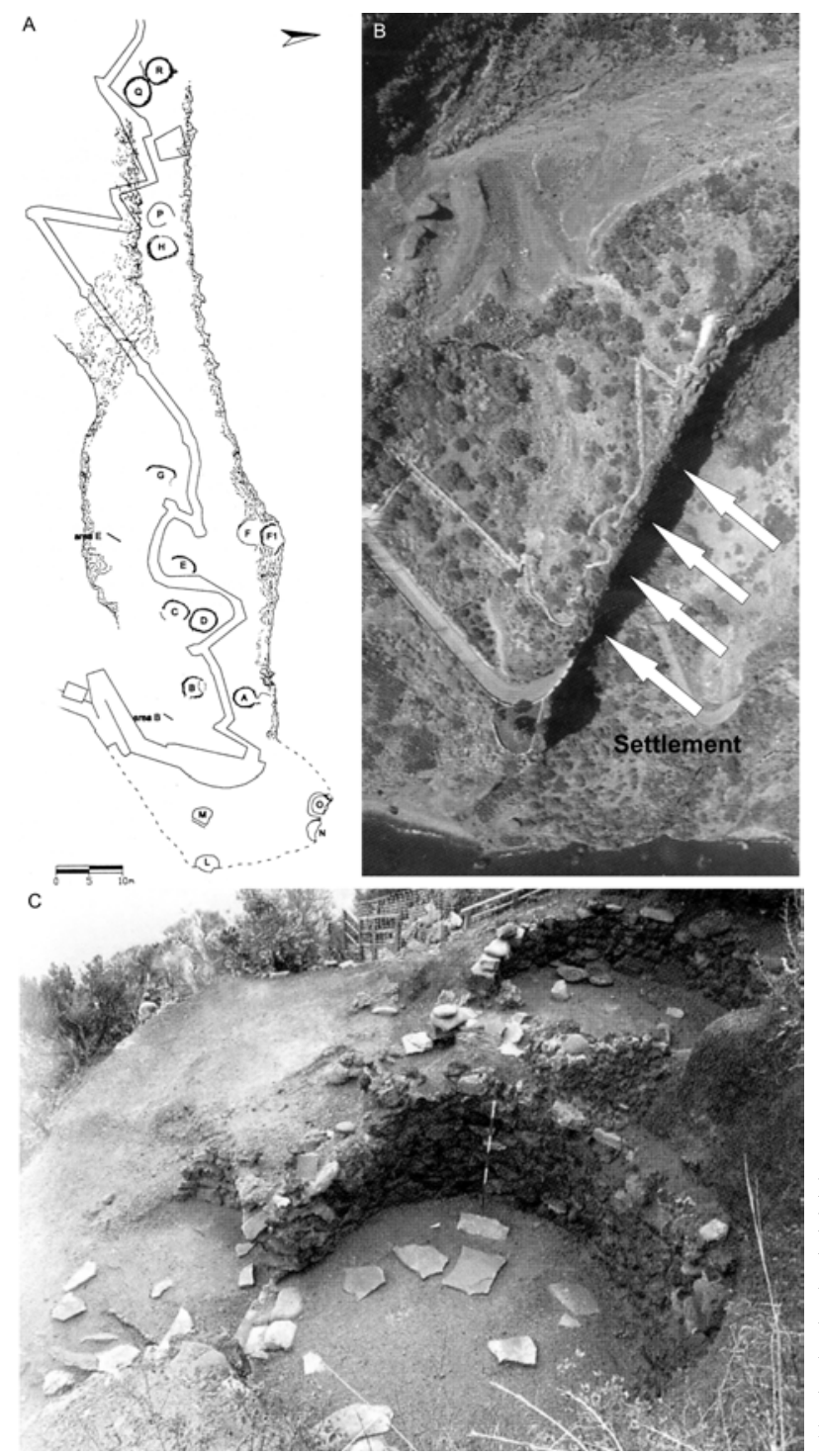

Figure 2 A) Portella settlement's site plan (after Martinelli 2005): huts A-H (hut I not showed) unearthed by Bernabò Brea and Cavalier excavations; huts L-R unearthed by Martinelli excavation (2000 campaign); B) aerial photo showing the settlement on Portella's rocky crest; C) Portella huts Q and R (B-C after Martinelli 2009, modified).

Capo Graziano), and Lipari (Acropoli) (Figure 1B), all the objects of excavations lead by Bernabò Brea and Cavalier (1968, 1980, 1991). Also, these villages yielded imports from Mycenaean Greece. The corpus of the Aegean sherds from the Aeolian Archipelago has been published at different points in time (Taylour 1958, 1980; Cavalier and Vagnetti 1984; Vagnetti 1991). More recently, a number of works have been published regarding (directly and indirectly) the use and appreciation of Aegean pottery by local communities (van Wijngaarden 2002; Vianello 2005) as well as its typological, chronological, depositional, and functional aspects (Bettelli 2002; Alberti and Bettelli 2005; Jung 2005, 2006; Alberti 2008a).

\section{RADIOCARBON SAMPLES FROM PORTELLA}

The 2000 campaign provided $7{ }^{14} \mathrm{C}$ determinations from 5 huts (L, M, N, O, and Q) (Table 2). The measurements were performed by the Department of Earth Sciences, University of Rome I "La 
Sapienza." After visual inspection using a binocular microscope, the samples underwent a sequential chemical decontamination $(\mathrm{HCl}-\mathrm{NaOH}-\mathrm{HCl})$ and were then converted to benzene. Dates were measured by liquid scintillation counting (LSC) with multichannel beta spectrometers (Calderoni and Martinelli 2005).

Table 2 Radiocarbon determinations from the Middle Bronze Age settlement at Portella on Salina Island (Milazzese facies) and from Middle Bronze Age strata at Rocavecchia settlement (Apulia, SE Italy; Apennine facies). Data from Martinelli (2005) for Portella and Pagliara et al. (2007) for Rocavecchia. Calibration performed with OxCal v 4.1.6 (Bronk Ramsey 2009), using the IntCal09 calibration curve (Reimer et al. 2009).

\begin{tabular}{|c|c|c|c|c|c|c|c|}
\hline Lab ID nr & Context & Provenance & Material & Species & $\begin{array}{l}{ }^{14} \mathrm{C} \text { age } \\
\mathrm{BP}\end{array}$ & $\begin{array}{l}\text { Calibrated } \\
\text { age } \\
(\mathrm{BCE}, 1 \sigma)\end{array}$ & $\begin{array}{l}\text { Calibrated } \\
\text { age } \\
(\mathrm{BCE}, 2 \sigma)\end{array}$ \\
\hline Rome-1247 & Port.-Hut O & Roof (hearth?) & Charred twig & Genista sp. & $3230 \pm 45$ & $1600-1437$ & $1612-1423$ \\
\hline Rome-1250 & Port.-Hut Q & l.s.i.d. ${ }^{\mathrm{a}}$ & Charred twig & Genista sp. & $3220 \pm 45$ & 1525-1436 & 1608-1416 \\
\hline Rome-1249 & Port.-Hut L & Roof & Charred twig & Genista sp. & $3210 \pm 45$ & 1516-1435 & $1608-1410$ \\
\hline Rome-1244 & Port.-Hut M & Hearth & Charred twig & Genista sp. & $3155 \pm 45$ & 1494-1398 & 1519-1316 \\
\hline Rome-1245 & Port.-Hut O & Roof & Charred twig & Genista sp. & $3150 \pm 40$ & 1491-1396 & 1506-1316 \\
\hline Rome-1248 & Port.-Hut L & Hearth? & Charred twig & Genista sp. & $3120 \pm 45$ & 1447-1317 & 1496-1271 \\
\hline Rome-1246 & Port.-Hut O & Roof (hearth?) & Charred twig & Genista sp. & $3110 \pm 45$ & 1434-1316 & 1493-1266 \\
\hline LTL 1523A & $\begin{array}{l}\text { Rocav.- } \\
\text { SAS X }\end{array}$ & US 5801 & Seed & $\begin{array}{l}\text { Triticum } \\
\text { dicoccum }\end{array}$ & $3204 \pm 40$ & 1504-1433 & 1606-1407 \\
\hline LTL 1525A & $\begin{array}{l}\text { Rocav.- } \\
\text { SAS X }\end{array}$ & US 5785 & Seed & $\begin{array}{l}\text { Triticum } \\
\text { dicoccum }\end{array}$ & $3180 \pm 50$ & 1500-1414 & 1606-1318 \\
\hline LTL 1462A & $\begin{array}{l}\text { Rocav.- } \\
\text { SAS X }\end{array}$ & US 5779 & Charred twig & $\begin{array}{l}\text { Myrtus } \\
\text { communis }\end{array}$ & $3103 \pm 35$ & $1427-1318$ & $1446-1271$ \\
\hline LTL 1460A & $\begin{array}{l}\text { Rocav.- } \\
\text { SAS X }\end{array}$ & US 5785 & Charred twig & Phyllirea sp. & $3074 \pm 35$ & 1403-1313 & 1426-1262 \\
\hline
\end{tabular}

a.s.i.d. = layer sealing internal deposit.

With the exception of hut Q, samples come from layers lying on the floor (Martinelli 2005). Four samples were from layers that have been identified with the collapse of the burnt roof on the original floor. In one case (Rome-1248 from hut L), a provenance from the hut's hearth has been proposed, but the actual presence of such a hearth is not altogether clear, and so a provenance from the burnt roof seems more likely. In another instance (Rome-1246 and -1247 from hut O), the assignment of the samples to the roof or to the hut's hearth is not clear, with the former perhaps more likely. For Rome-1244 from hut M, a provenance from the hearth seems more certain. Sample Rome-1250 from hut Q comes from the uppermost layer sealing the hut's internal deposit. This layer also sealed the adjoining hut $\mathrm{R}$.

The anthracological analysis showed that the samples are related to Genista sp., a short-lived species in archaeological terms. Relying on the available data, it seems in fact that both the dimensional aspects (samples are similar to twigs with a diameter of $\sim 4 \mathrm{~cm}$ ) and xilological features of this species (Calderoni and Martinelli 2005; Fiorentino 2005) rule out the possibility of its long circulation before the incorporation into the living context, since the wood would have begun to decay not long after being cut (Martinelli 2005). Consequently, no old-wood problem (Schiffer 1996; Bronk Ramsey 2009) would have affected Portella's ${ }^{14} \mathrm{C}$ dating: the event archaeologists are interested in (its use as a building material) is reasonably near the date at which the plant ceased to absorb ${ }^{14} \mathrm{C}$ (the cutting of the plant). 
Two further points are worth noting before delving into the core of this paper's argument. The first is the possibility for Portella's species to have absorbed old $\mathrm{CO}_{2}$ due to the volcanic nature of Salina Island. The issue of the drawback of the "old $\mathrm{CO}_{2}$ " on ${ }^{14} \mathrm{C}$ chronology has been recently stressed in relation to the Aegean chronological debate (Heinemeier et al. 2009; Wiener 2009). As for Portella, the volcanic activity on the island ended well before the Bronze Age, in a period estimated between 24 and 13 kyr BP (Ferlito 2005). This allows the negative effect of old $\mathrm{CO}_{2}$ on ${ }^{14} \mathrm{C}$ determinations from this island to be ruled out. The second point is that, at least as far as Bronze Age southern Italy is concerned, there does not seem to be any significant discrepancy between the ${ }^{14} \mathrm{C}$ chronology and historically dated deposits that could be a consequence of various natural phenomena (e.g. volcanic carbon vents) affecting the ${ }^{14} \mathrm{C}$ determinations. Although this issue has been recently addressed by Wiener (2009), the Bronze Age evidence from southern Italy shows that historical dating and ${ }^{14} \mathrm{C}$ chronologies are on the whole consistent (see e.g. Cazzella and Moscoloni 1994; Passariello et al. 2009). Consequently, such a phenomenon cannot be turned into a general rule for the region.

\section{RADIOCARBON CHRONOLOGY}

In the literature, 2 groups of dates have been devised on the basis of ${ }^{14} \mathrm{C}$, each representing a different phase of the settlement lifespan (Martinelli 2005). The stratigraphical position of sample Rome1250 has been highlighted: given its provenance, it seems clear that hut Q (as well as the adjoining hut R) was already dismantled at the date provided by the sample (Martinelli 2005). It is worth stressing that the literature lacks a definition of the time duration of the phase, as well as an estimate of its starting and ending boundaries.

It is this author's opinion that a different picture of the Portella chronology can be sketched out. What we are dealing with here is a group of determinations associated with archaeological material pertinent to a given cultural horizon. No a priori information that could provide sequential information is available. For these reasons, the approach taken here is twofold: to preliminarily check whether or not the data are consistent with the alleged hypothesis of group divisions; and to treat Portella's determinations as a phase in a simple Bayesian model (Buck et al. 1996), with the aim being to estimate the phase's start, end, and duration.

The analysis (Figure 3) was performed with the OxCal program v 4.1.6 (Bronk Ramsey 2009), using the IntCal09 calibration curve (Reimer et al. 2009). It must be noted that the hypothesis of the 7 dates being coeval cannot be rejected at $95 \%$ confidence, as the OxCal Combine function confirms $\left(\chi^{2}: T=6.50<12.60\right.$ for $\left.d f=6\right)$ (Ward and Wilson 1978). This weighs against devising any group divisions on a ${ }^{14} \mathrm{C}$ basis. As for the Portella determination defined as a single phase, besides the fact that the modeled probability distributions (solid distributions in Figure 3A) are narrower than those calculated in isolation (hollow likelihood distributions), the analysis indicates that the start of the phase is in the ranges $1502-1438$ cal BC (68.2\%) or 1556-1422 cal BC (95.4\%), with a most likely (modal) date of about $1450 \mathrm{cal} \mathrm{BC}$. The end is in the ranges 1443-1388 cal BC (68.2\%) or 14861336 cal BC (95.4\%), with a most likely date of $\sim 1415$ cal BC. Figure 3B shows the sum of the probability distributions of the dates ( $\mu 1445 \mathrm{cal}$ BC, $\sigma 28)$, which can be considered the best estimate of the distribution of the events. Additionally, the analysis indicates that the duration of the phase can be anything from 0-65 yr (68.2\%) or 0-131 yr (95.4\%).

In sum: a) the data are not consistent with group divisions; b) the Portella phase is likely to have been a very short one; and c) the most likely starting and ending boundaries are respectively equal to about 1450 and $1415 \mathrm{cal} \mathrm{BC.}$ 


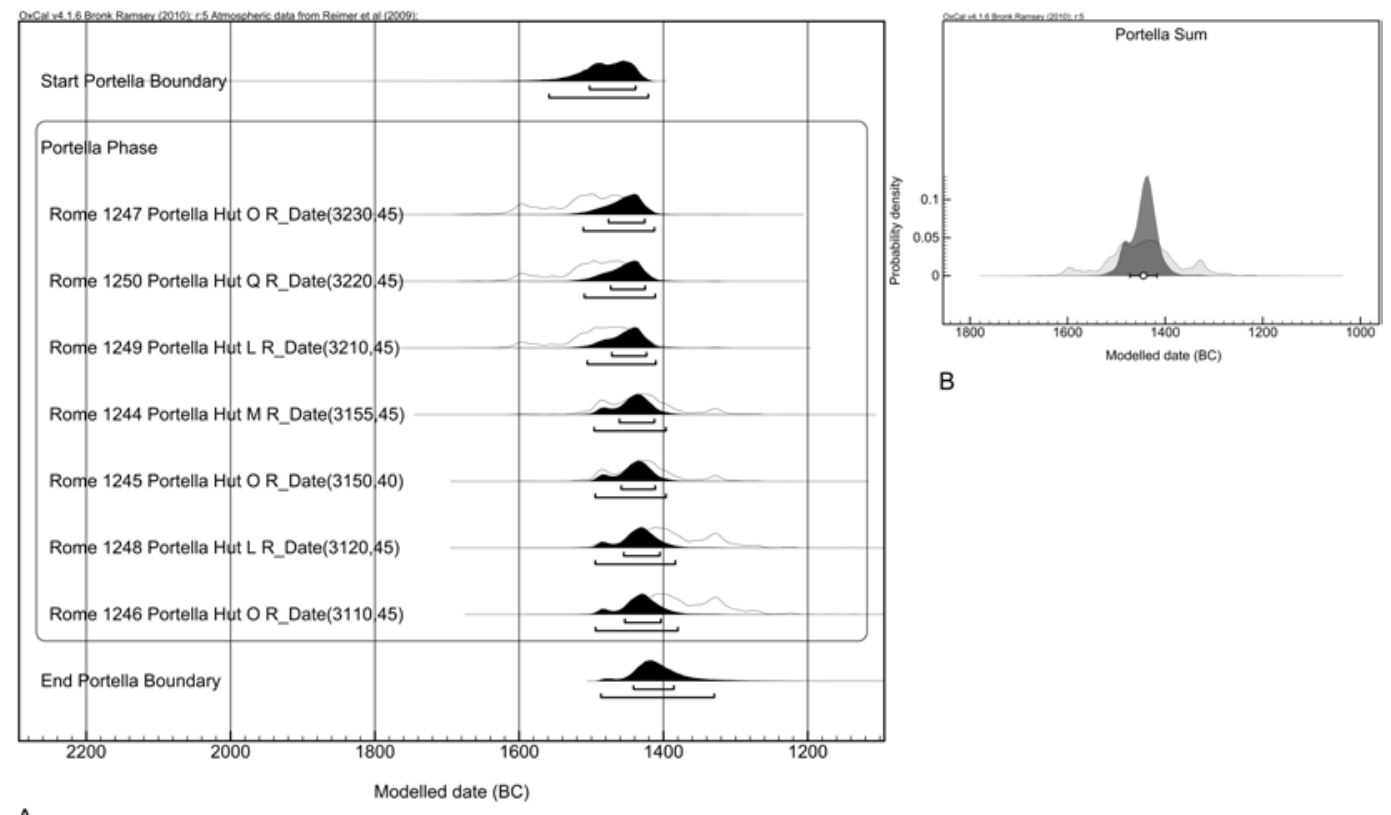

A

Figure 3 A) OxCal's Phase analysis: modeled calibrated date distributions for Portella phase; starting and ending boundaries of the phase are also shown; B) Diagram of the sum of the probability distributions of the dates in Portella phase, providing the best estimate of the distribution of the events ( $\mu 1445 \mathrm{cal} \mathrm{BC,} \sigma 28)$.

\section{DISCUSSION: CHRONOLOGICAL AND ARCHAEOLOGICAL IMPLICATIONS}

Important archaeological implications stem from the preceding analysis, from the standpoint of both the local cultural context and of the links with the Aegean chronology. The current ${ }^{14} \mathrm{C}$ evidence does not support devising any chronological difference between groups of huts. It could still be possible that group divisions had existed, but it is beyond the resolution of ${ }^{14} \mathrm{C}$ dating. What is striking is that the analysis of ${ }^{14} \mathrm{C}$ evidence, suggesting that the Portella phase is very likely to have been a short one, fits the analysis of the huts' ceramic assemblages found in layers pertinent to the huts' last stage of use (Alberti 2008a). Interestingly, this locates the Portella huts under discussion yielding diagnostic vessel types within the same Milazzese 1 phase, namely the earliest stage of the Aeolian MBA culture synchronized with the LH IIIA1 (Table 1). It seems that one cannot further resolve the events within those timespans, since they are beyond the resolution of both ${ }^{14} \mathrm{C}$ and ceramic typology. The only exception could be inherent to huts Q and R. It is worth repeating that sample Rome1250 , which is consistent with the others, comes from the top layer that sealed the internal deposit of hut $\mathrm{Q}$, and of the adjoining $\mathrm{R}$, when it had already been laid down. The sample constitutes a terminus ante quem for the period of use of these 2 cabins. Thus, only on stratigraphical grounds, they are likely to be earlier (but, admittedly, by an unknown amount) than the date provided by Rome1250 (Martinelli 2005; Alberti 2008a). Nonetheless, ceramic typology ascribes huts Q and R to the aforementioned Milazzese 1 phase.

The ${ }^{14} \mathrm{C}$ chronology of Portella is also interesting for its relevance to the absolute dating of Sicilian MBA culture and, indirectly, of the Aegean area. The development of Sicilian and Aeolian MBA has been linked to specific Aegean LH phases (Taylour 1958; Voza 1985; Vagnetti 1991; Jung 2005, 2006; Alberti 2007a, 2008a;) (Table 1). The upper chronological boundary of the period has been synchronized with LH IIIA1, while the lower one has been synchronized (though with different 
views among scholars) with part of LH IIIB. Interestingly, the start of the Portella phase turns out to be earlier than generally hypothesized for the start of the MBA (e.g. Taylour 1980; Leighton 1999; Pacciarelli 2001; Vianello 2005). There are grounds now to raise the beginning of MBA to early in the second half of the 15th century. Further, it is worth noting that the early chronology here devised for the Portella phase is bound to affect a number of archaeological issues related to the evidence from that site: a) the chronological relation to the preceding later stage of the Sicilian Early Bronze Age culture (Rodì-Tindari-Vallelunga facies); b) the chronological connection with Italian mainland Apennine culture, due to the presence of both Apennine and Apennine-type vessels in Portella contexts (see the analysis of the ${ }^{14} \mathrm{C}$ evidence from the site of Rocavecchia, below); and c) the chronology of the earliest metallurgical activity and presence of tin in Sicilian MBA contexts, since a casting mould and tin cramps have been found in a context pertinent to the aforementioned Hut R (Martinelli 2009; on tin see Lo Schiavo 2003; Kassianidou 2003; Alberti 2008b).

As for the Aegean chronology, given the link between the early stage of MBA and the LH IIIA1, which is confirmed by the evidence from both the Sicilian and Aeolian contexts (Jung 2006; Alberti 2008a), the Portella evidence gives support to an early start of LH IIIA1. The aforementioned Aegean fragmentary vessel from hut F, recently redated by Jung (2006) to the LH III A1, unfortunately comes from a context impossible to accommodate within the Milazzese ceramic sequence due to the lack of diagnostic ceramic types (Alberti 2008a). Still, the possibility for that LH IIIA1 vessel to be "in phase" with Portella's chronology stems from the following line of evidence. The later stage of the Aeolian Early Bronze Age (hereafter EBA), characterized by the Capo Graziano 2 culture, is featured by the presence of Aegean ceramic imports ranging from LH I to LH IIB (Table 1) (Taylour 1980; Vagnetti 1991; Jung 2006), which are remarkably absent from MBA horizons or, when present, are very likely to be residuals and/or intrusive from earlier strata (Alberti 2008a). On the basis of both stratigraphy and material culture, there is no evidence of overlap between the Capo Graziano and Milazzese facies, i.e. they were not contemporary. Consequently, the Aeolian EBA and its LH I-IIB imports must be earlier than the start of Portella, while the LH IIIA1 must span from the time period of Portella onward, until its lower boundary was constrained by the start of the subsequent LH IIIA2 (see Wiener 2003b; Table 1).

Supporting evidence comes from the MBA site of Rocavecchia, a fortified settlement lying in the Italian southeast (Apulia) (Pagliara 2005). Recent excavations in sector SAS X have exposed a stratified deposit spanning from the Middle to the Final Bronze Age (Pagliara et al. 2007). Four accelerator mass spectrometry (AMS) measurements on short-lived samples (Table 2) are available from the MBA level dating to the Apennine period (coeval of the Milazzese facies; Table 1). Measurements were made by the CEDAD laboratory (University of Salento, Lecce). Treating these determinations as a phase in a Bayesian framework (for the same reasons exposed before with regard to Portella), it is possible to estimate: a) the starting boundary, falling in the range 1529-1421 (68.2\%) or 1704-1395 (95.4\%) cal BC with a most likely (modal) date of $1449 \mathrm{cal} \mathrm{BC;} \mathrm{b)} \mathrm{the} \mathrm{ending} \mathrm{bound-}$ ary, falling within 1414-1298 (68.2\%) or 1433-1129 (95.4\%) cal BC with a most likely (modal) date equal to $1385 \mathrm{cal} \mathrm{BC}$; and c) the time duration: 21-133 yr (68.2\%) or 0-133 yr (95.4\%).

If we bear in mind that Italian mainland Apennine horizons are post-LH IIB in date (since LH IIB imports are present in earlier horizons but not in Apennine contexts; Alberti and Bettelli 2005; Jung 2006), there are grounds to believe that the evidence from Portella, and the interpretation here suggested, is consistent with that from Rocavecchia. Interestingly, both equally suggest that the MBA (Apennine and Milazzese facies) is likely to start around the mid-15th century BC; consequently, relying upon the present understanding of stratigraphy and ceramic imports, that period is likely to represent the starting boundary of LH IIIA1 as well. 
Finally, as far as the Aegean absolute dates are concerned, the hypothesis put forward here fits the current view of Aegean scholars. In spite of the earlier position pointing to LH IIIA1 starting from about 1400/1390 BC (Warren and Hankey 1989; Cline 1994; Warren 1998), it seems that a consensus is now growing about a pre-Amenhotep III for the start of that phase (Amenhotep III's reign: from 1390 to 1352 BC according to the Egyptian Middle Chronology; Wiener 2003b and references therein): see e.g. Manning (1995), Wiener (2003b) and Höflmayer (2009). Interestingly, the evidence here analyzed are consistent with Höflmayer's hypothesis of a LH IIIA1's start falling somewhere during the reign of Amenhotep II (1427-1400 BC), or, better, with the much debated hypothesis of a start before the end of Tuthmosis III's reign (1479-1425 BC) (Cline 1994; Manning 1995; criticism in Warren 1998; 1450 BC is considered acceptable by Macdonald 2001). It is this author's opinion that the Portella evidence can be useful for better defining the chronology of LH IIIA1, whose upper ceiling is poorly defined due to the lack of Aegean vessels found in securely datable contexts in Egypt or the Levant that could help to pinpoint the LH IIB-IIIA1 transition (Cline 1994; Höflmayer 2009). It is clear that the present hypothesis has to be cross-checked by means of new evidence on the absolute chronology of the Aegean phases immediately preceding the LH IIIA1. In this direction, interesting results could come from an Egyptian context (Saqqara tomb 16) in a forthcoming publication, which could contribute more information on the absolute chronology of the LH IIA (F Höflmayer, personal communication).

\section{CONCLUSIONS}

This article has attempted to show the potential of ${ }^{14} \mathrm{C}$ chronology in providing an insight into the chronological issues related to the Sicilian and Aeolian MBA contexts. The simple Bayesian analysis of the $7{ }^{14} \mathrm{C}$ determinations thus far available from Portella suggests that: a) the data are not consistent with group divisions between huts; b) the Portella phase is very likely to have been a short one, with an estimated span of 0-65 yr (68.2\%) or 0-131 yr (95.4\%); and c) the phase's start is in the range 1556-1422 cal BC (95.4\%), with a most likely date equal of $1450 \mathrm{cal} \mathrm{BC}$; the end is in the ranges 1443-1388 cal BC (68.2\%) or 1486-1336 cal BC (95.4\%), with a most likely date equal to about 1415 cal BC. Consequently, the start of the Sicilian MBA culture is likely to occur early in the second half of the 15th century BC. Further, the consistency of Portella's ${ }^{14} \mathrm{C}$ evidence has been stressed: d) with the ceramic typological chronology that assigned the assemblages from Portella huts objects of this article to the early stage of Aeolian MBA only (namely, Milazzese 1); and e) with the ${ }^{14} \mathrm{C}$ evidence from Rocavecchia on the Italian mainland. The Portella chronology leaves open the possibility to consider under a new light a number of archaeological issues, stemming from that site's documentation, such as the date of the earliest metallurgical activity and the presence of tin in Sicilian MBA contexts.

As far as the LH IIIA1ceramic style documented at Portella is concerned, it turns out that its relationship with Aeolian early MBA contexts is in agreement with the current view of Aegean scholars, pointing to the start of that style well before 1400/1390 BC. This analysis supports the hypothesis that LH IIIA1 started during the reign of Amenhotep II or, better, of Tuthmosis III. This is bound to contribute to a more clear definition of the absolute date of that Aegean phase.

In conclusion, more work needs to be done in relation to Sicilian contexts, especially analyzing the whole corpus of available data and planning specific research projects. Nonetheless, it is believed that the objectives in this paper can be a first step toward a deeper evaluation of the potential use of ${ }^{14} \mathrm{C}$ evidence in Sicilian prehistory and for assessing the extent to which Aegean and central Mediterranean chronologies can mutually benefit from such an evaluation. 


\section{ACKNOWLEDGMENTS}

I wish to thank (in alphabetical order) Elisabetta Borgna, Felix Höflmayer, Ray Kidd, Adam Michczyński, Annette Højen Sørensen, and Malcom Wiener for their invaluable comments, criticisms, and corrections on an early draft of this paper. I am grateful to the 2 anonymous reviewers for their constructive and encouraging comments, allowing me to greatly improve the manuscript. Thanks are due to Adam Michczyński and Malcom Wiener for providing me with many interesting articles. Sincere thanks go to Christopher Bronk Ramsey, Adam Michczyński, Andrew Millard, and the OxCal discussion group for replying to many questions of mine on the use of the OxCal program and on other aspects of ${ }^{14} \mathrm{C}$ dating. I am grateful to Ray Kidd for polishing the English text of an early draft of this article and for help on the use of the OxCal program. Last, but not least, I am grateful to Kimberley $\mathrm{T}$ Elliott for the patience and competence shown in editing the revised manuscript. Of course, I am solely responsible for any error or misunderstanding.

\section{REFERENCES}

Alberti G. 2004. Contributo alla seriazione delle necropoli siracusane. In: La Rosa V, editor. Le presenze micenee nel territorio siracusano. Padova: Bottega D’Erasmo. p 99-170.

Alberti G. 2007a. Minima Thapsiana. Riflessioni sulla cronologia dell'abitato di Thapsos. Rivista di Scienze Preistoriche 57:363-76.

Alberti G. 2007b. Review of Martinelli (a cura di), Il villaggio dell'età del Bronzo medio di Portella a Salina nelle Isole Eolie (Florence 2005). American Journal of Archaeology 111(2):373-4.

Alberti G. 2008a. La ceramica eoliana della facies del Milazzese. Studio crono-tipologico e culturale sulla base dei dati editi da Filicudi, Lipari, Panarea, Salina. BAR-IS 1767. Oxford: Archaeopress. In Italian with English summary.

Alberti G. 2008b. There is "something Cypriot in the air." Some thoughts on the problem of the Base Ring pottery and other Cypriot items from (local) Middle Bronze Age contexts in Sicily. In: McCarthy A, editor. Island Dialogues: Proceedings of the Postgraduate Cypriot Archaeology Conference (POCA) 2006. Edinburgh: University of Edinburgh Archaeology Occasional Papers 21. p 130-53.

Alberti L, Bettelli M. 2005. Contextual problems of Mycenaean pottery in Italy. In: Laffineur R, Greco E, editors. Emporia. Aegeans in the Central and Eastern Mediterranean. Eupen: Kliemo. Aegaeum 25:547-59.

Alessio M, Bella F, Cortesi C, Turi B. 1980. Datazione con il carbonio-14 di alcuni orizzonti degli insediamenti preistorici dell'Acropoli e di contrada Diana, isola di Lipari. In: Bernabò Brea L, Cavalier M, editors. Meligunìs Lipàra IV: L'acropoli di Lipari nella preistoria. Palermo: Flaccovio. p 839-44.

Bernabò Brea L. 1958. La Sicilia prima dei Greci. Milan: Il Saggiatore.

Bernabò Brea L, Cavalier M. 1968. Meligunìs Lipàra. Vol. III. Stazioni preistoriche delle isole Panarea, Salina e Stromboli. Palermo: Flaccovio.
Bernabò Brea L, Cavalier M. 1980. Meligunìs Lipàra IV: L'acropoli di Lipari nella preistoria. Palermo: Flaccovio.

Bernabò Brea L, Cavalier M. 1991. Meligunìs Lipàra VI: Filicudi. Insediamenti dell'età del bronzo. Palermo: Flaccovio.

Bettelli M. 2002. Italia Meridionale e Mondo Miceneo. Florence: All'Indegna del Giglio.

Bietak M. 2007. Bronze Age paintings in the Levant: chronological and cultural considerations. In: Bietak M, Czerny E, editors. The Synchronization of Civilizations in the Eastern Mediterranean in the Second Millennium B.C. III. Vienna: Verlag der Osterreichischen der Wissenschaten. p 269-300.

Bronk Ramsey C. 2009. Bayesian analysis of radiocarbon dates. Radiocarbon 51(1):337-60.

Buck CE, Cavanagh WG, Litton CD. 1996. Bayesian Approach to Interpreting Archaeological Data. Chichester: John Wiley \& Sons.

Calderoni G, Martinelli MC. 2005. Cronologia radiocarbonio. In: Martinelli MC. Il villaggio dell'età del Bronzo medio di Portella a Salina nelle Isole Eolie. Florence: Istituto Italiano di Preistoria e Protostoria. p 287-98.

Castellana G. 2000. La cultura del Medio Bronzo nell'agrigentino ed i rapporti con il mondo miceneo. Agrigento: Regione Siciliana-Museo Archeologico Regionale.

Cavalier M, Vagnetti L. 1984. Materiali micenei vecchi e nuovi dall'Acropoli di Lipari. Studi micenei ed egeoanatoloci 25:144-54.

Cazzella A, Moscoloni M. 1994. La cronologia dell’insediamento stratificato dell'età del Bronzo di Coppa Nevigata sulla base delle datazioni radiometriche. Origini 18:411-22.

Cline E. 1994. Sailing the Wine-Dark Sea. International Trade and the Late Bronze Age Aegean. BAR-IS 591. Oxford: Archaeopress.

D’Agata AL. 1997. L'unità culturale e i fenomeni di ac- 
culturazione: la media età del bronzo. In: Tusa S, editor. Prima Sicilia. Alle origini della società siciliana. Palermo: Ediprint. p 447-57.

D’Agata AL. 2000. Interactions between Aegean groups and local communities in Sicily in the Bronze Age. The evidence from pottery. Studi Micenei ed egeoanatolici 42(1):61-83.

De Miro E. 1999. Un emporio miceneo sulla costa sud della Sicilia. In: La Rosa V, Palermo D, Vagnetti L, editors. Epì Ponton Plazomenoi. Atti Simposio italiano di Studi Egei dedicato a Luigi Bernabò Brea e Giovanni Pugliese Carratelli. Rome: Scuola Archeologica Italiana ad Atene. p 439-49.

Ferlito C. 2005. Il territorio: geologia e vulcanologia. In: Martinelli MC. Il villaggio dell'età del Bronzo medio di Portella a Salina nelle Isole Eolie. Florence: Istituto Italiano di Preistoria e Protostoria. p 15-22.

Fiorentino G. 2005. Analisi archeobotanica. In: Martinelli MC. Il villaggio dell'età del Bronzo medio di Portella a Salina nelle Isole Eolie. Florence: Istituto Italiano di Preistoria e Protostoria. p 263-73.

Heinemeier J, Friedrich WL, Kromer B, Bronk Ramsey C. 2009. The Minoan eruption of Santorini radiocarbon dates. In: Warburton DA, editor. Time's Up. Dating the Minoan Eruption of Santorini. Athens: Danish Institute at Athens. p 285-94.

Höflmayer F. 2009. Aegean-Egyptian synchronisms and radiocarbon chronology. In: Warburton DA, editor. Time's Up. Dating the Minoan Eruption of Santorini. Athens: Danish Institute at Athens. p 187-96.

Jung R. 2005. Pote? Quando? Wann? Quand? When? Translating Italo-Aegean synchronisms. In: Laffineur R, Greco E, editors. Emporia. Aegeans in the Central and Eastern Mediterranean. Eupen: Kliemo. Aegaeum 25:473-84.

Jung R. 2006. Cronologia Comparata. Vergleichende Chronologie von Südgriechenland und Süditalien von ca. 1700/1600 bis 1000 v. u. Z. Wien: Verlag der Osterreichischen der Wissenschaten.

Kassianidou V. 2003. The trade of tin and the island of copper. In: Giumlia-Mair A, Lo Schiavo F, editors. Le problème de l'étain à l'origine de la métallurgie. The Problem of Early Tin. BAR-IS 1199. Oxford: Archaeopress. p 109-19.

Leighton R. 1999. Sicily before History. An Archaeological Survey from the Palaeolithic to the Iron Age. London: Gerald Duckworth \& CO.

Lo Schiavo F. 2003. The problem of early tin from the point of view of Nuragic Sardinia. In: Giumlia-Mair A, Lo Schiavo F, editors. Le problème de l'étain à l'origine de la métallurgie. The Problem of Early Tin. BAR-IS 1199. Oxford: Archaeopress. p 121-30.

Macdonald CF. 2001. Chronologies of the Thera eruption. American Journal of Archaeology 105(3):527-32.

Manning SW. 1995. The Absolute Chronology of the Aegean Early Bronze Age. Sheffield: Sheffield Academic Press.

Manning SW. 1999. A Test of Time: The Volcano of Thera and the Chronology and History of the Aegean and East Mediterranean in the Mid Second Millennium $B C$. Oxford: Oxbow Books.

Manning SW. 2009. Beyond the Santorini eruption: some notes on dating the Late Minoan IB period on Crete, and implications for Cretan-Egyptian relations in the 15th century BC (and especially LM II). In: Warburton DA, editor. Time's Up. Dating the Minoan Eruption of Santorini. Athens: Danish Institute at Athens. p 207-26.

Manning SW, Bronk Ramsey C. 2003. A Late Minoan III Absolute Chronology for the Aegean-Combining Archaeology with Radiocarbon. In: Bietak M, editor. The synchronization of Civilizations in the Eastern Mediterranean in the Second Millennium B.C. II. Vienna: Verlag der Osterreichischen der Wissenschaten. p 111-33.

Manning SW, Bronk Ramsey C, Kutschera W, Higham T, Kromer B, Steier P, Wild EM. 2006. Chronology for the Aegean Late Bronze Age 1700-1400 BC. Science 312(5773):565-9.

Martinelli MC. 2005. Il villaggio dell'età del Bronzo medio di Portella a Salina nelle Isole Eolie. Florence: Istituto Italiano di Preistoria e Protostoria.

Martinelli MC, editor. 2009. Museo Civico e Aree Archeologiche nel comune di Santa Marina Salina. Messina: Regione Siciliana.

Pacciarelli M. 2001. Dal villaggio alla città. La svolta protourbana del 1000 a. C. nell'Italia tirrenica. Citta di Castello: All’Insegna del Giglio.

Pagliara C. 2005. Rocavecchia (Lecce): il sito, le fortificazioni e l'abitato dell'età del bronzo. In: Laffineur R, Greco E, editors. Emporia. Aegeans in the Central and Eastern Mediterranean. Eupen: Kliemo. Aegaeum 25: 629-35.

Pagliara C, Maggiulli G, Scarano T, Pino C, Guglielmino R, De Grossi Mazzorin J, Rugge M, Fiorentino G, Primavera M, Calcagnile L, D’Elia M, Quarta G. 2007. La sequenza crono stratificata delle fasi di occupazione dell'insediamento protostorico di Roca (Melendugno, Lecce). Relazione preliminare della campagna di scavo 2005-Saggio X. Rivista di Scienze Preistoriche 57:311-62.

Passariello I, Albore Livadie C, Talamo P, Lubritto C, D’Onofrio A, Terrasi F. 2009. ${ }^{14} \mathrm{C}$ chronology of Avellino pumices eruption and timing of human reoccupation of the devastated region. Radiocarbon 51(2):80316.

Reimer PJ, Baillie MGL, Bard E, Bayliss A, Beck JW, Blackwell PG, Bronk Ramsey C, Buck CE, Burr GS, Edwards RL, Friedrich M, Grootes PM, Guilderson TP, Hajdas I, Heaton TJ, Hogg AG, Hughen KA, Kaiser KF, Kromer B, McCormac FG, Manning SW, Reimer RW, Richards DA, Southon JR, Talamo S, Turney CSM, van der Plicht J, Weyhenmeyer CE. 2009. IntCal09 and Marine09 radiocarbon age calibration curves, 0-50,000 years cal BP. Radiocarbon 51(4): 1111-50. 
Schiffer MB. 1996. Formation Processes of the Archaeological Record. Salt Lake City: University of Utah Press.

Taylour W. 1958. Mycenaean Pottery in Italy and Adjacent Areas. Cambridge: Cambridge University Press.

Taylour W. 1980. Aegean sherds found at Lipari. In: Bernabò Brea L, Cavalier M. Meligunìs Lipàra IV: L'acropoli di Lipari nella preistoria. Palermo: Flaccovio. p 793-817.

Vagnetti L. 1991. Appendice III. Le ceramiche egeomicenee. In: Bernabò Brea L, Cavalier M. Meligunìs Lipàra VI: Filicudi. Insediamenti dell'età del bronzo. Palermo: Flaccovio. p 263-305.

Vagnetti L. 1999. Mycenaean pottery in the central Mediterranean: imports and local production in their context. In: Crielaard JP, Stissi V, van Wijngaarden GJ, editors. The Complex Past of Pottery. Production, Circulation and Consumption of Mycenaean and Greek Pottery (Sixteenth to Early Fifth Centuries BC). Amsterdam: J C Gieben. p 137-61.

van Wijngaarden GJ. 2002. Use and Appreciation of Mycenaean Pottery in the Levant, Cyprus and Italy (ca. 1600-1200 BC.). Amsterdam: Amsterdam University Press.

Vianello A. 2005. Late Bronze Age Mycenaean and Italic Products in the West Mediterranean. A Social and Economic Analysis. BAR-IS 1439. Oxford: Archaeopress.

Voza G. 1985. I contatti precoloniali col mondo greco. In:
Pugliese Caratelli G, editor. Sikanie. Storia e civiltà della Sicilia greca. Milan: Credito Italiano. p 543-62.

Ward GK, Wilson SR. 1978. Procedures for comparing and combining radiocarbon age determinations: a critique. Archaeometry 20:19-31.

Warren P. 1998. Aegean Late Bronze Age 1-2 absolute chronology - some new contributions. In: Balmuth MS, Tykot RH, editors. Sardinian and Aegean Chronology: Towards the Resolution of Relative and Absolute Dating in the Mediterranean. Studies in Sardinian Archaeology V. Oxford: Oxbow Books. p 323-31.

Warren P. 2009. The date of the Late Bronze Age eruption of Santorini. In: Warburton DA, editor. Time's Up. Dating the Minoan Eruption of Santorini. Athens: Danish Institute at Athens. p 181-6.

Warren P, Hankey V. 1989. The Aegean Bronze Age Chronology. Bristol: Bristol Classical Press.

Wiener M. 2003a. Time out: the current impasse in Bronze Age archaeological dating. In: Foster KP, Laffineur R, editors. Metron. Measuring the Aegean Bronze Age. Liège: Université de Liège. Aegaeum 24: 363-95.

Wiener M. 2003b. The absolute chronology of Late Helladic IIIA2 revisited. Annual of the British School at Athens 98:239-50.

Wiener M. 2009. The state of debate about the date of the Theran eruption. In: Warburton DA, editor. Time's Up. Dating the Minoan Eruption of Santorini. Athens: Danish Institute at Athens. p 197-206. 